\title{
Resilience of the European Union as a determinant of its post-pandemic development
}

\author{
Mark ENTIN*, Dmitriy GALUSHKO**
}

\begin{abstract}
The article examines the category of "resilience" in the modern discourse of the European Union, its essence and characteristic features. The aim of the paper is to chart the complex process of the belated response of Brussels to the pandemic in the light of the concept of resilience of the Union, examining in detail the reasons for taken measures and its consequences for its future development, defining future scenarios. On the basis of the analysis, it is concluded that in modern conditions, resilience from an external category has gradually become internal for the EU. Moreover, this is relevant for the EU development in the context of today's COVID-19 pandemic and the challenges to European unity that it has caused. The authors review the key measures taken by EU institutions and bodies to combat the pandemic and provide economic assistance to member states to overcome its negative consequences. Based on the analysis carried out, three scenarios for the further development of the EU are proposed, and an opinion is expressed on the need to further ensure the resilience of the Union itself. Since, in any case, the pandemic has demonstrated that the era of nation states in the region is finally a thing of the past, and Europe needs much greater unity and cohesion.
\end{abstract}

Keywords: resilience, pandemic, COVID-19, European Union, European integration, development

\section{Introduction}

The first EU document that identified resilience as a key concept was the programme of support for drought-affected countries in the Horn of Africa adopted in November 2011. Thus, the emergence of a systemic interest in the category of resilience coincided in the European Union with its actualization in the discourse of the UN global governance. It should be noted that the UN system is given a key place

\footnotetext{
* Mark ENTIN is Professor at the MGIMO University, Moscow, Russia; email: entinmark@gmail.com.

${ }^{* * *}$ Dmitriy GALUSHKO is Associate Professor at the Financial University, Moscow, Russia; e-mail: galushkodv@gmail.com.
} 
in the EU's vision of the present and the future world order as it embodies the principles of multilateralism and the rule of law which are at the core of the European integration model itself. The discourses of the United Nations and the European Union on international development assistance and global governance are closely interlinked. It is no accident that the EU's originally formulated approach to resilience in general did not go beyond the UN discourse (EEAS, 2016).

The situation began to change due to the combination of overlapping challenges that the European integration model faced in the following years. Over the past twelve years, the EU has been hit by a cascade of crises. The first global financial and economic crisis, for which the integration organisation was unexpectedly completely unprepared, was followed by the sovereign debt crisis. The negative consequences of that events and the side effects they provoked, which caused the degradation of the political and socio-economic sphere, have not been completely overcome by the countries of the region to date. On the other hand, in order to effectively confront new dangers and challenges and to stabilize the situation, ensuring EU resilience, they have gone to a serious systemic deepening of integration. Now it was already not only about the resilience of developing countries and not even about the resilience of the EU's closest neighbours, but also about the future of the European project itself. And conceptually it responded in part with "A Global Strategy for the European Union's Foreign and Security Policy" (2016), which replaced a document of a similar nature, namely, the European Security Strategy (2003). "Resilience" became the cornerstone for a renewed approach to the security problems of the EU (Treshchenkov, 2019).

The likelihood that the need for joint efforts, mutual assistance and the implementation of coordinated policies will again push member states to deepen integration is relatively high. Moreover, at the end of 2019, in a somewhat different environment, they began to discuss Franco-German ideas for the accelerated convocation of the Convention, the third in the history of the EU, designed to reform the integration project (European Sources Online, 2020).

The purpose of this paper is to chart the complex process of the belated response of Brussels to the pandemic in the light of the concept of resilience of the Union, examining in detail the reasons for taken measures and its consequences for its future development, defining future scenarios. Taking into account the lessons of the pandemic, it defines factors that impacted the practical policy of the EU and its member states, analysing the determinism of how the European elites intend to respond to them as well as the imprint that the success or, conversely, the failure of these attempts can impose on the ensuring of the Union's resilience. This contribution is therefore written under the caveat that the analysis is, by definition, far from complete and merely aims to serve as an attempt to predict the future development of the European Union after the pandemic in the context of the need of ensuring its resilience. 
The methodological basis of the study consists of a number of general scientific approaches to the issues of resilience, integration, regional cooperation, the EU's responses to crises and its post-pandemic development. The conducted scientific research was based on the principles of objectivity, historicism, pluralism, consistency, dialectics, determinism, complexity and systematics. The specifics of the study led to the use of a number of methods of cognition, namely: philosophical, general scientific, legal scientific and the forecasting method. Institutional, comparative-historical and dialectical methods were also used in writing the paper. They helped to comprehensively consider the research question.

Building on this, the paper brings a contribution to the future planning of the European Union's development and is structured as follows: firstly, it starts from the EU discourse on resilience, turning to the modern problem of the COVID pandemic as the main threat to the Union's resilience and its future development; secondly, section 2 contains analysis of the main steps taken by the Union and member states as a response to the pandemic, having shown the power of the United Europe. And thirdly, based on the analysis, contained in the previous section, section 3 reveals consequences of the taken measures along with attempts to define factors, that influenced disjointed response to the COVID threat. In turn, summarising the research in the conclusion, it is crucial to draw up three scenarios of the EU's development with the need to continue to provide its resilience.

\section{Essence of the concept «resilience» in EU perspective}

The category of resilience was introduced in 1973 by the Canadian ecologist K. Holling. He argued that any system that manages to survive has resilience, that is, the ability to adapt and recover from shocks (Holling, 1973). Almost immediately, resilience as "the science of a complex adaptive system and operational strategy established itself as the dominant discourse in natural resource management" (Walker and Cooper, 2011). The development of strategies for maintaining resilience in various spheres of society has become the main line of modern debates. Resilience is essentially an organizational principle of the modern political life (Brasset et al., 2013, p. 222), which includes elements of various formulations proposed by scientists and practitioners (Carver, 1998), and requires further research as governance modes are always evolving (Zemanova, 2012). From a practical point of view, it should be noted that the concept of "resilience" is broader than just "overcoming", since it includes two concepts: resistance to destruction, that is, the ability of a person to protect his or her integrity when under strong pressure; and also, in addition to simple resistance, the ability to build a full life in difficult conditions: such "creation" implies moving in a certain direction for a certain time. Thus, "resilience" means not just overcoming difficulties by society and returning to the previous state as it was before the difficulties arose, but progress, moving forward due to difficulties to a new stage of life. 
Real world problems and disasters that are important for analysing various aspects of the concept of resilience include a wide range of phenomena from the impact of natural disasters, such as earthquakes or hurricanes, wars and terrorist attacks. At present, of course, we can talk about the COVID-19 pandemic. However, all these threats around the world have not yet destroyed the motivation of people to live and develop.

The persistence and severity of various crises within the European Union gives grounds for studying the ability of this integration entity to cope with all these threats and the prospects for its further development. And if initially within the EU, resilience was considered as an external category, then recently, taking into account objective circumstances, it has gradually become an internal category for the EU. Thus, research has begun to focus on various aspects that affect the understanding and perception of resilience of the entire European integration project. In this regard, we support the approach that resilience is actually an element of the European society's ability to strengthen pan-European security, and cannot be limited by military, economic, legal and political aspects. The concept itself should be expanded to include political and psychological components. In a democratic society, aspects such as trust in government and public institutions and patriotism play an important role in political participation and social capital (Sullivan and Transue, 1999), which in turn leads to higher levels of resilience (Canetti et al., 2014). Thus, resilience is also considered as a process of adaptation and "absorption" of problems or changes caused by an external threat.

The question of success in resilience is complicated due to multiple interpretations of its nature - either as a reaction or as a permanent state (Wojtowicz, 2020 , p. 6). Some scholars believe that resilience is the ability of a society to withstand adversity and crises in various areas by making changes and adapting without compromising the basic values of society and its institutions (Friedland, 2006). However, the level of resilience of an international integration entity can be considered in two different directions. On the one hand, resilience characterizes the ability of a society to withstand challenges with its values and institutions intact (Kimhi and Eshel, 2009). On the other hand, such resilience can be reflected in adjustments and adaptations, such as behavioural adaptations that help "close the gap" between the current stress and the needs of the community and its capabilities ${ }^{1}$. In addition, new behavioural patterns, as a response to a threat, create new political and social relationships that can characterize the system's ability to overcome crisis situations and conflicts.

\footnotetext{
${ }^{1}$ Elran, M. Israel's National Resilience: The Influence of the Second Intifada on Israeli Society, Tel Aviv: Jaffe Center for Strategic Studies, Tel Aviv University, (2006), https://www.inss.org.il/publication/israels-national-resilience-the-influence-of-the-secondintifada-on-israeli-society/.
} 
Adopted in June 2016, the EU's Global strategy for foreign and security policy cemented stabilization and assistance in building the resilience of societies and States in the EU's neighbouring regions as an important condition for ensuring the resilience of the European model itself. Resilience has been defined as the ability of an individual, household, community, country, or region to withstand stress and shocks, adapt to them, and recover quickly from them.

The EU Council adopted the basic principles of resilience: the responsibility of the national government for resilience, working together on the EU and member states' resilience taking into account national specificities, long-term cooperation with international organizations, national and regional context, the integration of resilience in all EU relations with relevant countries, work with civil society and local community partners, respect for gender equality.

Choosing the term "resilience" as central to the Global Strategy (and it is repeated more than 40 times there) is largely due to the crisis phenomena and the EU's desire to find a solution to them.

Work on the preparation of the Global Strategy began in 2015 and lasted almost two years. During this period, the European Union faced a huge number of both old, but qualitatively transformed, and new risks and threats. Their acuteness was so great that it made us talk about the existential challenges of the EU. These included internal economic problems (especially the instability of the monetary Union), the influx of refugees, which called into question the joint responsibility in the European Union, and the imbalances in internal development, euroscepticism and Brexit, which many associated with the beginning of the collapse of the EU. In external relations, the EU is increasingly accused of failing to respond to the challenges of the modern world (including terrorism, cyber security), of the small impact of its international efforts, of the gap between value rhetoric and practice activities, of the lack of coordination in the international arena in economy, politics, security and development assistance. Moreover, in the perception of the authors of the Global Strategy, the world consensus on the liberal order itself was called into question (Tocci, 2017, pp. 61-63).

The rapid spread of the COVID-19 pandemic has become a global challenge that requires a quick search for effective responses. For the EU member states of the European Union, this crisis is threatening in several dimensions. Firstly, this is an urgent crisis in the health system, which has the potential to provoke a socioeconomic crisis. Secondly, the COVID-19 pandemic calls into question the basic principles of the EU's functioning, in particular freedom of movement within the Schengen area or solidarity in response to common threats. Thirdly, the ability of EU institutions to provide timely assistance or at least coordinate responses from member states in crisis situations is called into question as well. Fourth, the search by member states for individual ways to counter COVID-19 has sharpened domestic political discussions and opened a window of opportunity for other geopolitical players. In the end, the crisis led to a discussion about the EU's vulnerability through 
"infodemic" - an information pandemic caused by an excess of low-quality false content distributed through social networks that affects public sentiment and political decisions.

In any case, throughout the EU, the implementation of systematic and effective measures to combat the pandemic was delayed, when an extremely important time was lost. They underestimated their lack of preparedness and the weakness of their health systems. Some European leaders, like French President Emmanuel Macron, have even found the courage to admit it. The measures introduced each time were given an increasingly strict and compulsory character gradually or in stages only after it turned out that they were insufficient and unable to stop the spread of the coronavirus (later, Russia, alas, repeated these mistakes). All countries acted on their own, sometimes even to the detriment of their partners in the bloc. As a result, the EU started implementing a much-needed joint policy only when it was no longer necessary to prevent an economic and social crisis, but rather to mitigate and neutralize its consequences.

\section{The potential power of united Europe}

And at this stage, the EU as an integration entity, albeit with a costly delay, managed to show many of its inherent advantages and opportunities. It was as if it heard the call of the leaders of European political parties to rehabilitate themselves for their clumsiness and stop the centrifugal tendencies with the thoughtfulness and power of their actions ${ }^{2}$. The variety and scope of the measures it plans and organizes, even if its officials attribute to it what is being done by member states, are commendable. The summary report of the European Council of April 9 contained 23 points, each of which looked more than significant (European Council, 2020).

At a joint press conference in Brussels just a week later, on April 15, 2020, the European Commission President Ursula von der Leyen and the European Council President Charles Michel announced with a note of both bitterness and pride that they had accumulated 3 trillion euro (!) together with the EU countries to stop the pandemic, save the labour market, support businesses and restore the economy. They promised that even more funds (European Commission, 2020a) will eventually be raised and allocated for this purpose.

The European Commission and the European Council will combine all the steps already taken and discussed to get out of the self-isolation regime into a single road map designed to ensure better coordination, efficiency and synergy. And serious, life-changing changes will be made to the budget targets for the next sevenyear budget cycle 2021-2027 (European Commission, 2020b). In Italy, they were

\footnotetext{
${ }^{2}$ Stanishev, S., Why Europe must act now, and on a big scale, EU Observer, 9 April 2020 (retrieved from https://euobserver.com/opinion/148023?utm_source=euobs\&utm_ medium=email).
} 
even hastily dubbed the new Marshall plan for the $\mathrm{EU}^{3}$, inspired by the promise to attract about 1.5 trillion euro for joint spending from the free financial market ${ }^{4}$.

For an objective assessment of today and tomorrow of an integration entity, it is important to emphasize that it has acquired these advantages and opportunities in two stages as a result of the reforms required first to overcome the global crisis (2009-2011), then, the sovereign debt crisis (2012-2013). Due to the complex nature of the reforms, it has modernized legislation and worked out mechanisms for largescale repurchases of debt and securities (hundreds of billions of euros), providing loans to the most affected countries, monitoring budget discipline and the stability of the banking and insurance sectors, and giving the newly created supervisory, regulatory and coordinating bodies far-reaching powers (Tuori and Tuori, 2014).

The EU has taken basically three types of anti-crisis actions. They can be divided into negative, positive in the financial sphere and positive in the field of coordination and protection of the real sector of the economy. By negative measures, we mean the rejection of what would prevent us from mitigating the consequences of the crisis. Positive in the financial sphere means the allocation of funds to support everything that is possible: countries, businesses, the labour market, the selfemployed, households, and vulnerable groups. Positive in the manufacturing sector is to overcome the dependence on imports in several critical sectors and the challenges of self-sufficiency.

In the light of multibillion individual and collective support programs for people and businesses and complaints from countries in the Southern and Eastern parts of the Union about the inaction of a United Europe, some of the specific financial assistance measures it has taken have gone almost unnoticed. Such measures were provided almost immediately to individual member states. But their volumes, by ordinary standards, cannot be estimated as absolutely insignificant. In particular, Brussels relatively quickly notified Budapest and Warsaw that they can spend on their own needs and at their own discretion 1 billion euros, which they were obliged to return to the Cohesion Fund, which serves to reduce the economic and social gap between the prosperous and not so rich EU member states. In this regard, the media even made fun of the governments of Hungary and Poland, which in the EU were assigned the name "nationalist". In the context of their claims to the EU, they were reminded of an ancient anecdote with almost 5 thousand years of history: "One of the wedding guests scolds it for nothing. They say that the wedding is bad, and the food is lousy. The main thing — he adds, — was that it wasn't enough"s.

\footnotetext{
${ }^{3}$ Affarinternazionali, Exit Strategy dell'Ue: serve un nuovo piano Marshall, 17 April 2020 (retrieved from https://www.affarinternazionali.it/2020/04/exit-strategy-dellue-serve-unnuovo-piano-marshall/).

${ }^{4}$ EU Observer (2020), EU anti-crisis budget 'could be up to $€ 1.5$ trillion (retrieved from https://euobserver.com/tickers/148043?utm_source=euobs\&utm_medium=email).

${ }^{5}$ Meyer-Resende, M., The price of a European order, EU Observer, 8 April 2020 (retrieved from: https://euobserver.com/opinion/148009).
} 
In fact, the promise of the European Central Bank (ECB) alone was enough to return to acceptable interest rates at which Italy could borrow on the free financial market and place its debt obligations. That without this, the economy of any EU member state, even one of the EU grandees, is vulnerable, was demonstrated by the collapse of markets when ECB President Christine Lagarde rashly stated that the Bank's mandate is not to deal with this.

Writing off her blunder, the ECB announced a new program of "quantitative easing" in the amount of a whopping 750 billion euros - the Pandemic Emergency Purchase Programme (PEPP), which, taking into account previously planned spending, will amount to 1 trillion euros. This time, the ECB promised to use these funds primarily to buy out the debt obligations of member states, thereby providing them with much-needed liquidity, or, in other words, as in 2008-2009 and 20122013, flooding the fire of a new global economic crisis with an unsecured flow of money (European Central Bank, 2020a). A little earlier, it decided to spend an additional 120 billion euros by the end of the year on a quantitative easing program to buy back private sector securities (ECB, 2020).

In addition, the ECB launched a long-term refinancing operations program (LTROs) and unveiled a regulatory package that provides for temporary easing of requirements for interim measures. Under them, structures that are in partnership with the Eurosystem can participate in programs to fill the market with liquidity and provide loans (European Central Bank, 2020b).

Before that, it mitigated its capital requirements for the system-forming banks of European countries that it oversees, thereby encouraging them to continue lending money to enterprises in the real sector of the economy (ECB, 2020c). In turn, the European banking authority transmitted a recommendation to national banking regulators to make similar decisions (European Banking Authority, 2020). It suggested that they should also change the qualification of late payments. A little later, their example was followed by the Basel Committee on banking supervision ${ }^{6}$.

In response to the plans of member states to attract unprecedented huge resources to save national economies, the EU first of all not only mitigated, but also lifted the basic restrictions of the Monetary and Financial Union and the Stability Pact on sovereign debt levels, budget deficits and current account balances (European Commision, 2020). Even for a while. In addition, it hastened to approve revised, much more flexible rules for providing state aid. Checking the actions of national authorities for compliance with the requirements of EU rules, of course, remained in force. However, the European Commission began to apply them in order to mitigate the devastating effects of the 2020 pandemic on national economies. So, on April 6, 2020 it approved the General scheme for providing state aid to small and medium-sized enterprises for 56.8 billion euros, developed by the British

\footnotetext{
${ }^{6}$ Bank of International Settlements (2020), Basel Committee of Baking Supervision Measures to reflect the impact of COVID-19 (retrieved from https://www.bis.org/bcbs/publ/d498.htm).
} 
government (until the end of the transition period, the United Kingdom continued to remain in the area of EU law), but did so already by applying the revised rules ${ }^{7}$.

In General, the arsenal of funds that can be used as anti-crisis funds accumulated by the EU in recent years is more than impressive. There is a multibillion stabilization mechanism - the EU's potbelly, which can be used. There is an opportunity to strengthen the financial position of all the weaker and shakier economies by socializing debt. At the first stage of the pandemic, it was about issuing joint debt obligations, in which Germany's participation would give them a completely different quality. There is a current budget, which could quickly made the necessary changes. Especially in the structure of the EU's seven-year budget planning.

But for all this, it would be necessary to coordinate the approaches of the member states, to convince some of them to sacrifice narrowly understood national interests. And that's where the «dog is buried» turned out to be. As for the European Commission, it promptly decided to allocate up to fifty billion euros in aid to member states: including 37 billion from the current budget and various EU funds for the Coronavirus Response Investment Initiative. For its part, the European Investment Bank has allocated 40 billion euros for the same purposes: maintaining the health system, the labour market, and small and medium-sized enterprises. Given that the EU budget does not exceed 1\% of the GDP of its member states, this is more than a significant amount - the maximum that the Commission had the right to afford. By April, the European Commission has prepared plans worth 100 billion euros to help companies that are ready to refuse to lay off temporarily unemployed employees, and generally prevent a recession ${ }^{8}$. Earlier, the Commission also made a proposal to change the EU regulation on the EU Solidarity Fund in order to increase the amount of aid allocated to it (European Parliament, 2020).

Member states could do much more. But for a very long time, given the speed of the growing crisis phenomena, they are stuck in endless disputes that hit the EU's Holy of holies - the foundations of solidarity, discrediting the integration entity, increasing the discontent felt by each other by the economically stable core of the EU and its less prosperous Mediterranean periphery.

While member states were fighting among themselves, rather than with the coronavirus, the European Commission had an additional chance to rehabilitate itself, and it began to act much more decisively and thoughtfully. Thus, its President, Ursula von der Leyen, and the Commissioner responsible for the internal market, Thierry Breton, managed to re-profile a number of industries to produce vital medical equipment. This was done thanks to their direct appeal to the management

\footnotetext{
${ }^{7}$ EU Observer, EU approves UK's coronavirus state-aid business plan, 7 April 2020 (retrieved from https://euobserver.com/tickers/148000?utm_source=euobs\&utm_medium=email).

${ }^{8}$ Sandford, A., Coronavirus in Europe: EU science chief quits, slamming response to pandemic, Euronews, 8 April 2020 (retrieved from https://www.euronews.com/2020/04/08/ acoronavirus-in-europe-eu-science-chief-quits-slamming-response-to-pandemic).
} 
of aircraft, automobile and other companies ${ }^{9}$. Let us also recall the achievements of the Commission in providing financial support to member states, especially to some of them, as mentioned above.

Condescendingly explaining the European Commission's «low profile», representatives of Western political circles and the expert community nod to the EU's lack of supranational powers in the field of health, which is still entirely the responsibility of member states. Leading Russian experts (Babynina, 2020) also write about this. However, even in this respect, even if belatedly, it began to show itself as a coordinator of the actions taken, using some of its existing powers. So, on April 8, the European Commission appealed to all Schengen countries as a common visa space of the EU and other acceding European countries (Iceland, Liechtenstein, Norway and Switzerland), Bulgaria, Cyprus, Croatia and Romania to extend the ban on unnecessary travel to May 15, explaining that self-isolation from the infected with coronavirus begins to benefit only after 30 days.

The Commission has also begun to make up for lost time in organizing broad international cooperation and caring for countries and peoples in distress. It has performed best in redirecting financial resources from other needs (humanitarian aid, technical assistance, poverty reduction, etc.) to the fight against the pandemic. By mid-April, the EU's European external action service, which has taken the lead in this area, announced the allocation of more than 20 billion euros to help countries in Africa, the Western Balkans, the Eastern partnership and countries in need in the Middle East, North Africa, Asia and Latin America in order to prevent the further spread of the disease and create prerequisites for more effective treatment of those infected. The money should be used to solve a wide range of humanitarian problems, support health systems, and overcome the social and economic consequences of the pandemic (RIA-Novosti, 2020a).

The set of planned actions to provide assistance was dubbed "Team Europe". The package will combine both the EU and its member States' own resources, as well as specialized financial institutions created by the integration entity - the European Investment Bank and the European Bank for Reconstruction and Development. According to the EU's foreign policy service, it will serve as another tranche of aid in addition to the 15.6 billion euros that the Commission and European Investment Bank announced earlier about re-profiling from other existing aid programs. Thus, Armenia was promised to be allocated 92 million euros for the fight against coronavirus, etc. (RIA-Novosti, 2020b). Another 3 billion euros will go to help individual countries in the Eastern neighbourhood, the Balkans and the Mediterranean (European Commission, 2020b).

\footnotetext{
${ }^{9}$ Kumar, I., "No single country will be left behind in this crisis" says EU Commissioner for Internal Market, Euronews, 3 April 2020 (retrieved from https://www.euronews.com/ 2020/04/03/no-single-country-will-be-left-behind-in-this-crisis-says-eu-commissioner-forinternal-ma).
} 


\section{European (dis)Union in time of the crisis?}

The delayed response to the pandemic revealed the EU's weaknesses, lack of solidarity, and inability to act coherently and decisively in non-standard situations. "There was a shortage of vital medical equipment, critical production chains were disrupted, hundreds of thousands of people lost their jobs, which brought business and industry to their knees", popular TV hosts described the situation as of the beginning of April $2020^{10}$.

A series of scandals revealed the EU's clumsiness, bureaucratization, and inability to quickly adapt to a rapidly changing, especially emergency situation. One of them, in particular, was the high-profile resignation of the newly appointed President of the European Research Council, the EU's leading structure in this field, a specialist in nano medicine, Mauro Ferrari. In a statement to the Financial Times ${ }^{11}$, he explained his resignation as a total "disappointment in the European response" to the pandemic and a "loss of faith in and respect for the EU system" as a whole.

Mauro Ferrari said that at the initial stage of the spread of the disease on the continent, when every day, every hour was important, he tried to launch a holistic, systematic program of pan-European research designed to stop it. However, he was not let to do it, being pointed out that the Council does not work like this. He doesn't hand out orders from above. That's not how it works. It is designed to support the initiative from below and choose the best of the proposed projects. The scientist helped the Commission's President develop the EU action program, but it was drowned in endless objections and approvals. The EU structures, of course, hastened to disavow the scientist, gave dozens of arguments refuting his words, but, in fact, expressed only their version of events ${ }^{12}$.

The crisis was triggered by panicked, unilateral, fragmented measures taken by EU countries. "After trying to maintain open borders in the first weeks of March, the European Commission was forced to change course and recognize the legality of border control, trying to mitigate its impact by adopting guidelines" (Potemkina, 2020). They recommend that member states, at a minimum, coordinate and report on the protective measures taken. Everyone tried to separate themselves from each other, instead of looking for a joint solution. In doing so, they did not so much help themselves, as made life difficult for others. In addition, the damage to both national economies and the Common market as a whole has significantly increased.

The closure of borders and the introduction of border and passport controls caused a transport collapse. Tens of thousands of trucks crowded the emergency restored checkpoints. Queues for travel stretched for many kilometres. None was

\footnotetext{
${ }^{10}$ Kumar, I. (2020).

${ }^{11}$ Ferrari, M., Return to the frontlines, to the frontier, FT, 2020, (retrieved from http://produpp-image-read.ft.com/65f5a27e-78dd-11ea-af44-daa3def9ae03).

12 Sandford (2020).
} 
notified in a timely manner. Nothing has been done to ensure a reasonable speed of border crossing by cargo transport providing mutual supply. None thought about the conditions of drivers who were stuck at the border for several days.

The closure of borders, combined with the uncoordinated, arbitrary, and everywhere different shutdown of enterprises, led to a break in production chains. As a result, the production facilities that could work were also up and running. But they were counted on. And in respect of them measures of epidemiological safety have not been imposed. Consequently, businesses that could have been taken out of harm's way have also suffered. The financial and economic situation of the member states has deteriorated to a greater extent than it would have if they had applied unified anti-crisis measures. Unemployment has jumped. There were many more workers at risk than expected. It is not for nothing that the OECD, which compiled it, placed the preservation of production chains in second place in the list of priorities for bringing the world economy out of the crisis facing states, right after ensuring transparency in regulating trade flows (RIA-Novosti, 2020a).

The reason for this is that the member states made another gross political miscalculation - they failed to assess the scale of the COVID-19 coronavirus pandemic in time, to form a united front in the face of a new extremely dangerous threat, and to speak from a unified position quickly and energetically. "Europe has failed", "Europe has failed", "Europe has failed", - have made a depressing verdict, trying to express in one word their attitude to what happened in the hope that in the future the EU will fully rehabilitate itself ${ }^{13}$. We can define several circumstances that explain their miscalculation, their disjointed and inhibited reaction.

1) The World Health Organization (WHO), on whose warnings and recommendations everyone is counting, has behaved in a frankly contradictory way. It took a flexible position, carefully monitoring the development of the situation with the spread of the disease in China, then around the world, but for an unacceptably long time it did not draw any decisive conclusions. The chronicle of events published by the BBC in connection with the investigation launched in the United States shows this with all certainty ${ }^{14}$, although its experts later gave the chronicle a more evasive interpretation ${ }^{15}$. As a result, all states, with the exception of the initial centres of distribution of the coronavirus, were disoriented. Instead of launching a system of preparatory and preventive measures in a timely manner, they waited. For which everyone paid very bitterly.

\footnotetext{
${ }^{13}$ Meyer-Resende, M, Nobody's fault? Europe's sleepwalk into disaster, EU Observer, 22 April 2020 (retrieved from https://euobserver.com/opinion/148134?utm_source= euobs\&utm _medium=email).

${ }^{14}$ BBC, Coronavirus: US to halt funding to WHO, says Trump, 15 April 2020 (retrieved from https://www.bbc.com/news/world-us-canada-52289056).

${ }^{15}$ Reality Check Team, Coronavirus: Is President Trump right to criticise the WHO? BBC News, 15 April 2020 (retrieved from https://www.bbc.com/news/world-us-canada52294623).
} 
2) The European Union and its member states were let down by the frivolous attitude of the potential threat. In Europe, they pretended that the new malicious and dangerous strain was only a Chinese, local problem. Let the Chinese fight it. An indirect recognition of this can be found in the words of Thierry Breton, a member of the European Commission responsible for the internal market: "At the end of last year, we encountered a virus in China. I'll tell you the truth. No one took it seriously. Only after the Chinese turned to us for help in early January, the situation changed"16.

3) The EU artificial blindness was also caused, perhaps primarily, by their information war against China. Therefore, using their dominance in the information sphere, China's geopolitical rivals were quick to accuse it, when everything was just beginning, of being negligent, of "sleeping through" the epidemic and, in order to hide the truth from people, first excommunicated doctors who rushed to ring the bells, then anyone who could discredit the measures taken. But by mid-March 2020, when the situation has changed radically, China managed to suppress the spread of the disease, cases of infection were no longer registered in the country, and the entire mass of newly ill people was made up of those coming and returning from abroad. On the contrary, Italy, Spain, France and other EU countries have become the main centre of the spread of the pandemic, and the United States has fenced them off with a complete closure of air traffic. And they all had the opportunity to look in the mirror at all the accusations and reproaches that they threw at Beijing. The measures they decided on were much more severe and violent than the Chinese ones, including the imposition of a state of emergency, restrictions on personal freedoms, the involvement of security forces, administrative and criminal prosecution for violating the regime of isolation and self-isolation. "For many governments, blaming China for everything," the Royal Institute of International Affairs reports, among other things, "seemed like the best way to distract attention from the fact that they themselves were sitting in a puddle" (O'Neill, 2020).

4) It should be also admitted the factor of exhaustion of unified approaches to solving common problems. The coronavirus pandemic, we would like to believe, made the EU leadership and the leading member states understand how different the EU countries are. Even when they follow the same program, do the same thing, take seemingly identical measures, they get completely different results. And the spread is very large. This cannot be ignored. The second lesson is that no matter how far integration goes, no matter what is done at the supranational level, as soon as the specter of danger appears on the horizon, or when the EU fails, or there is a feeling that it fails, the member states resort to nationalization of EU policy. But if so, it is important that (a) it does not harm others; (b) the case does not suffer from it; (c) each country has at least a minimum potential

${ }^{16}$ Kumar (2020). 
for solving problems independently while common approaches are developed and the structures of the integration association take over. Experts from the EU countries put the question very correctly: "States have once again become the main actors in the fight against the crisis, which raises doubts about the future of the EU and its institutions. Is it possible to state the death of the EU? Not at all. But it will have to change. The main thing is to understand how" ${ }^{17}$. Responding to it, they emphasize: with a much clearer reading of the principle of subsidiarity, as mentioned above, but at the same time giving the European project a fundamentally different flexibility. Consequently, the EU will have to diversify its attitude towards its member states in order to ensure its resilience, coming to the following conclusions. It is necessary that a slightly different policy be applied to each of them, taking into account their specifics, national traditions, state of affairs, level of development, etc. At the same time, it is important that, as far as possible, as far as the imperatives of the uniform functioning of the single market allow, different requirements are imposed on each of them on the same grounds.

Thus, a wide range of measures and their integrated implementation were required to effectively counter the pandemic and mitigate its severe economic and social consequences. Each EU member state at the initial stage of the crisis began to invent and try them out on their own. As a result, the standard requirements of the integration entity to focus on best practices were violated.

The situation in the EU has been dubbed by politicians, experts and a significant part of the population of the member states with the pejorative formula "every man for himself". It was blamed on the integration organisation and its institutions. What is happening in the EU gave thousands of reasons for this. However, in reality, it is not the EU institutions that should be responsible for it in the field of health, Brussels really does not have far-reaching exclusive or mixed, but only supporting powers (Babynina, 2020) - but national governments. But the latter could not deny themselves the opportunity to blame everything on the EU institutions. Otherwise, they would have to admit their own slowness and lack of foresight, weakness and helplessness, and unforgivable mistakes and failures.

Perhaps this explains why many politicians and representatives of the expert community have tried to explain that the EU is suitable "only for good weather". It has resilience, being effective and coping well with its duties when everything is calm, when everything is going well for it. It is not adapted to emergency calls. When emergency situations occur, it begins to slip and show innate weaknesses.

\footnotetext{
${ }^{17}$ Massaux, A. (2020), Coronavirus: l’Union européenne à la croisée des chemins. Plus que jamais, il va être important que le principe de subsidiarité de l'UE soit mis en avant: l'Union doit offrir un soutien tout en prenant en compte la diversité de ses members, Contrepoints (retrieved from https://www.contrepoints.org/2020/03/27/367544-coronavirus-unioneuropeenne-a-la-croisee-des-chemins).
} 
Oddly enough, the conclusion that can be drawn from such a statement, regardless of how justified it is, is directly opposite to the accusatory pathos of EU detractors and eurosceptics of the old leaven. It is that if the EU is not adapted, it must be reformed in such a way that it can respond quickly and effectively to emergencies, to do what member states have not yet dared to do, providing own resilience.

\section{Conclusions}

Theoretically, there are three main scenarios for the development of the European Union after the pandemic subsides and member states begin to return to normal life, and many intermediate ones.

The essence of the first of them is to return to business as usual. The EU is restoring integration mechanisms that have been affected by the pandemic, and this is limited. All four classic freedoms of the common market are back in effect. All previously imposed restrictions on freedom of movement are lifted. The EU's Schengen law is being renewed, etc. It seems that this is the easiest thing to do, and in any case, you need to do it first.

The second scenario assumes that the demonstrated neglect of each other's interests, concern exclusively for their own salvation and their own interests, and often at the expense of others, will set the political elites to prioritize the strengthening of independence through the cohesion and integrity of the integration entity. The member states will stake on strengthening national mechanisms, national economies, their own crisis management capabilities, not the EU. Centrifugal tendencies will prevail. It will be impossible to restore the integration project in its previous form. It will suffer greatly.

The third scenario follows the development of the first and is directly opposite to the second. According to it, political elites come to the conclusion that all the troubles associated with the pandemic and its political and socio-economic consequences are caused by insufficient, incomplete, and half-hearted integration. Accordingly, they are taking a course to consolidate and strengthen the EU. They rely on deepening integration, transferring new powers to the supranational level, creating more effective supranational mechanisms and procedures, completing the common market and adding new unions to it.

In fact, member states have no choice. Neither the first nor the second scenario gives any of them the opportunity to overcome the dire consequences of the pandemic (perhaps, with the exception of Germany, and even then it is unlikely it depends too much on access to the markets of EU partners), to neutralize all the colossal damage that it has inflicted and will continue to inflict on national economies and society, to ensure resilience of the Union. The pandemic has shown that the era of nation states in the region is finally a thing of the past. Much greater unity and cohesion is needed. 
This is exactly what Angela Merkel said when she addressed the peoples and political elites of the region on April 6, 2020: "Everyone has suffered equally [from the coronavirus pandemic]. It is in the interests of all and in the interests of Germany that Europe comes out stronger from the ordeal" ${ }^{\prime 8}$. It is echoed by all Euro-optimists in Europe. The pandemic has failed to force them to abandon their beliefs. They emphasize: "The EU must be given much more powers in order to cope with the leadership role in the future" 19 .

Together with all the others, to some extent in support of what was discussed above, Euroenthusiasts point out: «The governments of all member states were poorly prepared and made mistakes». But from this, following the logic that they are used to following, they draw the only possible conclusion for them: «Instead of scolding the EU or each other, it is time for all member states to focus on finding solutions. Germany, the Netherlands and others must understand that a rapid economic recovery will not happen if the rest of Europe fails. The southern EU countries should recognize that financial obligations imply accountability to other member states for the expenditure of public funds». Eastern member states - that it is necessary to strictly adhere to the common values of the EU and pay back solidarity for solidarity. Only then will all the tremendous achievements made over the years of the European project bear fruit, and it will be possible to move forward ${ }^{20}$. However, how EU resilience will be ensured, and what scenario it will take, will hugely depend on the conclusions that the European elites will draw from the lessons of the pandemic.

\section{References}

Babynina, L. (2020), Koronavirus: chto mozhet sdelat' i delaet Evropejskij sojuz, IE RAN, Analiticheskaja zapiska, 12(195), pp. 1-8 (retrieved from http://www.instituteofeurope.ru/images/uploads/analitika/2020/an195.pdf).

Brasset, J., Croft, S. and Vaughan-Williams, N. (2013), Introduction: An Agenda for Resilience Research in Politics and International Relations, Politics, 33(4), pp. 221-228. https://doi.org/10.1111/1467-9256.12032

Canetti, D., Waismel-Manor, I., Cohen, N. and Rapaport, C. (2014), What Does National Resilience Mean in a Democracy? Evidence from the United States and Israel, Armed Forces \& Society, 40(3), pp. 504-520. https://doi.org/10.1177/0095327X12466828

\footnotetext{
${ }^{18}$ Zalan, E., Merkel: Virus is biggest challenge in EU history, EU Observer, 7 April 2020 (retrieved from https://euobserver.com/coronavirus/148003?utm_source=euobs\&utm_ medium=email).

${ }^{19}$ Meyer-Resende, M. (2020).

${ }^{20}$ idem.
} 
Carver, C.S. (1998), Resilience and Thriving: Issues, Models, and Linkages, Journal of Social Issues, 54(2), pp. 245-266. https://doi.org/10.1111/0022-4537.641998064

European Banking Authority (2020), EBA statement on actions to mitigate the impact of COVID-19 on the EU banking sector, 12 March (retrieved from https://eba.europa.eu/eba-statement-actions-mitigate-impact-covid-19-eu-bankingsector).

ECB (2020), Monetary policy decisions, Press-release, 12 March (retrieved from https://www.ecb.europa.eu/press/pr/date/2020/html/ecb.mp200312 8d3aec3ff2 .en.html).

ECB (2020a), ECB announces $€ 750$ billion Pandemic Emergency Purchase Programme (PEPP), Press-Release, 18 April (retrieved from https://www.ecb.europa.eu/press/pr/ date/2020/html/ecb.pr200318_1 3949d6f266.en.html).

ECB (2020b), ECB announces package of temporary collateral easing measures, PressRelease, 7 April (retrieved from https://www.ecb.europa.eu/press/pr/date/2020/html/ ecb.pr200407 2472a8ccda.en.html).

ECB (2020c), ECB Banking Supervision provides temporary capital and operational relief in reaction to coronavirus, Press-release, 12 March (retrieved from https://www.ecb.europa.eu/press/pr/date/2020/html/ecb.pr200312 45417d8643.en.htl.

European Commission (2020a), Coronavirus: European roadmap shows path towards common lifting of containment measures, Press release, 15 April (retrieved from https://ec.europa.eu/commission/presscorner/detail/en/ip_20_652).

European Commission (2020b), Coronavirus: Commission proposes 3 billion euro macrofinancial assistance package to support ten neighbouring countries, Press release, 22 April (retrieved from https://ec.europa.eu/commission/presscorner/detail/en/ ip_20_716).

European Commission (2020c), Communication from the Commission to the Council on the activation of the general escape clause of the Stability and Growth Pact, Brussels, March 20, $\operatorname{COM(2020)~} 123$ final.

European Council (2020), Report on the comprehensive economic policy response to the COVID-19 pandemic, 9 April (retrieved from https://www.consilium.europa.eu/en/ press/press-releases/2020/04/09/report-on-the-comprehensive-economic-policyresponse-to-the-covid-19-pandemic/).

European External Action Service (2016), Shared Vision, Common Action: A Stronger Europe. A Global Strategy for the European Union's Foreign and Security Policy, Brussels, 28 June (retrieved from https://europa.eu/globalstrategy/en/shared-visioncommon-actionstronger-europe).

European Parliament (2020), Proposal for a Regulation of the European Parliament and of the Council amending Council Regulation (EC) No. 2012/2002 in order to provide financial assistance to Member States and countries negotiating their accession to the Union seriously affected by a major public health emergency, Brussels, $\operatorname{COM}(2020) 114$ final 2020/0044 (COD), 13 March (retrieved from https://ec.europa.eu/info/sites/info/ files/regulation-coronavirus-financial-assistance-accession-countries-march2020_en.pdf). 
European Sources Online (2020), Conference on the Future of Europe 2020-2022, April (retrieved from https://www.europeansources.info/record/conference-on-the-future-ofeurope-2020-2022/).

Friedland, N. (2006), Introduction - The 'Elusive' Concept of Social Resilience, in: Friedland, N., Arian, A., Kirschenbaum, A. and Fleischer, K.A. (eds), The Concept of Social Resilience, Haifa: The Technion, Samuel Neaman Institute, pp. 7-10.

Holling, C.S. (1973), Resilience and stability of ecological systems, Annual review of ecology and systematics, 4(1), pp. 1-23. https://doi.org/10.1146/annurev.es.04.110173.000245

Kimhi, S. and Eshel, Y. (2009), Individual and Public Resilience and Coping with Long- Term Outcomes of War, Journal of Applied Biobehavioral Research, 14(2), pp. 70-89. https://doi.org/10.1111/j.1751-9861.2009.00041.x

Meyer-Resende, M. (2020b), Nobody's fault? Europe's sleepwalk into disaster, EU Observer, 22 April (retrieved from https://euobserver.com/opinion/148134?utm_source= euobs\&utm_medium=email).

O’Neill, J. (2020), Blaming China is a Dangerous Distraction, Chatham House, 15 April (retrieved from https://www.chathamhouse.org/2020/04/blaming-china-dangerousdistraction).

OECD (2020), COVID-19 and International Trade: Issues and Actions, Tackling Coronavirus (COVID-19), Contributing to a Global Effort, June 12 (retrieved from https://read.oecdilibrary.org/view/?ref=128_128542-3ijg8kfswh\&title=COVID-19-and-internationaltrade-issues-and-actions).

Potemkina, O. (2020), Evropejskij sojuz: ogranichenie peredvizhenija grazhdan kak sredstvo bor'by s COVID-19, IE RAN, Analiticheskaja zapiska №14 (197) (retrieved from http://www.instituteofeurope.ru/images/uploads/analitika/2020/an197.pdf).

RIA-Novosti (2020a), EC vydelit 20 milliardov evro na bor'bu s COVID-19 za predelami Evropy (retrieved from https://ria.ru/20200408/1569777489.html).

RIA-Novosti (2020b), ES predostavit Armenii 92 milliona evro na bor'bu s koronavirusom, 8 April (retrieved from https://ria.ru/20200408/1569775397.html).

Sullivan, J.L. and Transue, J.E. (1999) The Psychological Underpinning of Democracy: A Selective Review of Research on Political Tolerance, Interpersonal Trust, and Social Capital, Annual Review of Psychology, 50(1), pp. 625-650. https://doi.org/10.1146/annurev.psych.50.1.625

Tocci, N. (2017), Framing the EU Global Strategy. A Stronger Europe in a Fragile World, Cham, Palgrave Macmillan. https://doi.org/10.1007/978-3-319-55586-7

Treshchenkov, E. (2019), Resilience in Discourses of the European Union and International Organizations, International Organisations Research Journal, 14(1), pp. 55-75. https://doi.org/10.17323/1996-7845-2019-01-04

Tuori, K. and Tuori, K. (2014), The Eurozone Crisis. A Constitutional Analysis, Cambridge: Cambridge University Press. https://doi.org/10.1017/CBO9781107297289 
Walker, J. and Cooper, M. (2011), Genealogies of Resilience: From Systems Ecology to the Political Economy of Crisis Adaptation, Security Dialogue, 42(2), pp. 143-160. https://doi.org/10.1177/0967010611399616

Wojtowicz, N. (2020), Resilience against intentional shocks: a wargaming study of the relation between space, action and the residing population to resilience, Eastern Journal of European Studies, 11(1), pp. 5-26.

Zalan, E. (2020), Merkel: Virus is biggest challenge in EU history, EU Observer, 7 April (retrieved from https://euobserver.com/coronavirus/148003?utm_source=euobs\&utm_ medium=email).

Zemanova, S. (2012), The Europeanization of official development assistance: EU governance by cooperation - communication and domestic change, Eastern Journal of European Studies, 3(1), pp. 31-48. 